\title{
VALIDATION OF FOUR MALAXIS SPECIES (ORCHIDACEAE)
}

\author{
ROBERT L. DRESSLER
}

Missouri Botanical Garden; Florida Museum of Natural History; Marie Selby Botanical Gardens Mailing address: 21305 NW 86th Ave., Micanopy, Florida 32667, U.S.A.

\begin{abstract}
Names of four species of Malaxis, described as new without a Latin diagnosis in Selbyana 24(2), 2003, are validated here.

RESUMEN. Se validan los nombres de cuatro especies de Malaxis descritas como nuevas sin diagnosis latina en Selbyana 24(2), 2003.
\end{abstract}

KeY WORDS / PALABRAs ClAVE: Orchidaceae, Malaxis, nomenclature.

In a recent article (Dressler 2003) I had intended to publish four new species of Central American Malaxis, but I inadvertently omitted the necessary Latin diagnoses (although I carefully thanked F. Pupulin for his help with the missing Latin diagnoses.) I here publish the diagnoses needed to validate the species described in the Selbyana paper. The pagination in Selbyana 24(2), 2003 is indicated for each species after the correspondent name.

Malaxis brevis Dressler (141)

Malaxidi hastilabiae (Rchb.f.) Kuntze similis, sed flore multo minori, auriculis uncinatis usque ad deltoideis, labelli cavitatibus brevissimis dignoscenda.

Malaxis insperata Dressler (142)

Floris illis Malaxidis brachyrrhynchote (Rchb.f.) Ames similes, sed plantae cormis conicis.

Malaxis rostratula Dressler (142)

Flos ille Malaxidis aureae Ames similis, sed labello breviore profundiore abrupte rostrato.
Malaxis triangularis Dressler (143)

A Malaxidi corymbosae (S. Wats.) Kuntze labello triangulari acuto recedit.

Incidentally, if I had checked the proper computer file (Dressler 2001), the paper in Selbyana would have been entitled "Mesoamerican orchid novelties $6, "$ though I see no profit in changing the title at this late date.

LITERATURE CITED

Dressler, R.L. 2001. Mesoamerican orchid novelties: 4, Habenaria. Bol. Inst. Bot. Univ. Guadalajara 7: 93-101.

Dressler, R.L. 2003. Mesoamerican orchid novelties 4, Malaxis. Selbyana 24(2): 141-143. 